\title{
DNA methylation and adaptive response in forest tree species
}

\author{
Angeles Guevara', Enrique Sáez', Luis-Manuel Díaz', Tamara Herranz', Carmen Barbero', Dolóres Vélez', \\ Carmen Collada², David Sánchez-Gómez ${ }^{3}$, Ismael Aranda', Teresa Cervera ${ }^{{ }^{*}}$ \\ From IUFRO Tree Biotechnology Conference 2011: From Genomes to Integration and Delivery \\ Arraial d Ajuda, Bahia, Brazil. 26 June - 2 July 2011
}

Progressive increase of temperatures as well as longer seasonal drought periods revealed by climate studies correspond to fast environmental changes that forest species face with their actual genetic background. Natural selective processes cannot develop an adaptive response within this time frame. Thus the capability of forest tree species to adapt to the new environments will depend on their genetic background, but also rely on their phenotypic plasticity. Several reports have shown the involvement of epigenetic modifiers as the basis of the phenotypic plasticity, and in particular to the adaptation to abiotic stresses. DNA methylation (methylation of cytosine residues)is one the most important epigenetic modification in eukaryotes. Itis involved in specific biological processes such as gene transcription regulation, gene silencing, mobile element control or genome imprinting.Therefore, there is a great interest in analyzing cytosine methylation levels and distribution within the genome.

In order to analyze methylation-sensitive anonymous CCGG restriction sites we used MSAP technique (Methylation-Sensitive Amplified Polymorphism), an AFLP-based technique for the analysis of cytosine methylation. The technique is based on the use of isoschizomers that show differential cleavage sensitivity to cytosine methylation. HpaII and MspI are isoschizomers that are frequently used to detect cytosine methylation. HpaII cannot cleave if one or both cytosines are fully methylated (in both strands), whereas $M s p$ I cleaves $\mathrm{C}^{5 \mathrm{~m}} \mathrm{CGG}$ but not ${ }^{5 \mathrm{~m}} \mathrm{CCGG}$ sequences). For each sample, MSAP analysis is performed using both EcoRI/HpaII and $E c o$ RI/MspI digested samples. Comparative analysis

\footnotetext{
* Correspondence: cervera@inia.es

'Dpto. Ecología y Genética Forestal, CIFOR-INIA, Ctra.de La Coruña km 7, 28040 Madrid, Spain

Full list of author information is available at the end of the article
}

between EcoRI/HpaII and EcoRI/MspI fragment patterns allows the identification of two types of polymorphisms: (1) "Methylation-insensitive polymorphisms" that are associated with genetic variability and will show common EcoRI/HpaII and EcoRI/MspI profiles among samples; and (2) "Methylation-sensitive polymorphisms" that are associated with epigenetic variability and detected as amplified fragments differing in their presence or absence or in their intensity between EcoRI/HpaII and EcoRI/MspI patterns of the same sample. Thus, full methylation of the internal cytosine at the assayed CCGG sites will be associated with fragments detected in EcoRI/MspI pattern which are absent or less intense in EcoRI/HpaII profile. Hemi-methylation of the external cytosine will be associated with fragments observed in EcoRI/HpaII pattern which are absent in EcoRI/MspI profile.

We have optimized DNA methylation analysis for two forest tree species, including both angiosperm (Fagus sp.) and gymnosperm (Pinus sp.) species.

The set-up of the MSAP technology has allowed study intra-specific variability of DNA methylation in Pinus pinea L. a specie which is characterized by a low genetic variability and high level of phenotypic plasticity. Representative populations spanning the whole distribution of this specie within Spanish geography were chosen for this study, including coastal and interior populations. MSAP patterns from vegetative propagated trees were compared among and within populations. Percentage of methylation-sensitive polymorphisms was calculated and selective markers were identified.

To test a possible role of DNA methylation in the plasticity of Fagus sylvatica L. in response to water deficit we analyzed two populations of beech from Spain and Sweden which differ in the response to water stress. Patterns of DNA methylation clearly differed between 
populations. Although the rate of DNA methylation was similar between irrigated and non-irrigated trees in each polpulation after AMOVA, some specific MSAPs associated with water stress response were identified.

\section{Author details}

'Dpto. Ecología y Genética Forestal, CIFOR-INIA, Ctra.de La Coruña km 7, 28040 Madrid, Spain. ${ }^{2}$ Dpto. de Biotecnología. ETSIM (UPM), Ciudad

Universitaria s/n, 28040 Madrid, Spain. ${ }^{3}$ Dpto. Silvopasticultura. ETSIM (UPM),

Ciudad Universitaria s/n, 28040 Madrid, Spain.

Published: 13 September 2011

doi:10.1186/1753-6561-5-S7-P86

Cite this article as: Guevara et al: DNA methylation and adaptive response in forest tree species. BMC Proceedings 2011 5(Suppl 7):P86.

Submit your next manuscript to BioMed Central and take full advantage of:

- Convenient online submission

- Thorough peer review

- No space constraints or color figure charges

- Immediate publication on acceptance

- Inclusion in PubMed, CAS, Scopus and Google Scholar

- Research which is freely available for redistribution

Submit your manuscript at www.biomedcentral.com/submit 